\title{
Polychaete assemblages on the Magellan and Weddell Sea shelves: comparative ecological evaluation
}

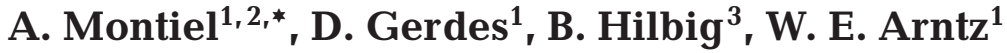 \\ ${ }^{1}$ Alfred Wegener Institut für Polar- and Meeresforschung, Columbusstrasse, 27568 Bremerhaven, Germany \\ ${ }^{2}$ Laboratorio Hidrobiología, Instituto de la Patagonia, Universidad de Magallanes, Casilla 113 D, Punta Arenas, Chile \\ ${ }^{3}$ Ruhr-Universität Bochum, Universitätsstrasse 150, 44780 Bochum, Germany
}

\begin{abstract}
Similarities between the soft-bottom polychaete assemblages on either side of the Drake Passage and spatial patterns of these assamblages were analysed based on data from 273 corer samples collected in the Magellan region (42 to $55^{\circ} \mathrm{S}, 254 \mathrm{~m}$ mean water depth) and on the Weddell Sea shelf $\left(70\right.$ to $71^{\circ} \mathrm{S}, 263 \mathrm{~m}$ mean water depth). Paraonidae, Ampharetidae and Maldanidae were the most abundant families in the Magellan region, while in the Weddell Sea, Syllidae, Terebellidae and Spionidae were most abundant. The total species number found in the Magellan region (199) was higher than in the Weddell Sea (163), and significantly higher values of heterogeneity diversity, species richness and density were found in the Weddell Sea. At most of the Weddell Sea stations, all 3 trophic guilds (suspension feeders, detritus feeders and predators) were present, whereas suspension feeders were almost absent in the Magellan samples. The species abundance distribution showed a high number of species represented by only 1 specimen in both regions. This causes low dominance and similar high values of evenness in both regions. We suggest that the polychaete assemblage structures in both regions are influenced by environmental stress through ice and the physical complexity of the areas, which results in many different habitats.
\end{abstract}

KEY WORDS: Polychaetes · Species composition · Diversity · Geographic distribution · Trophic guilds Magellan region $\cdot$ Weddell Sea

\section{INTRODUCTION}

Soft bottoms are the most common habitats in the world's ocean (Wilson 1991, Snelgrove 1998). Traditionally, the understanding of community patterns in this kind of habitat has been an important task of marine ecology (Gray 2002). Many studies over the last 30 yr have compared community attributes along depth (Sanders 1968, Rex et al. 1993, Gray 1994, Cosson-Sarradin et al. 1998) or latitudinal gradients (Ellingsen 2001, Clarke \& Johnston 2003, Valdovinos et al. 2003). Recently, scientific interest has also concentrated on zoogeography and diversity patterns (Gaston 1996, Foggo et al. 2003, Barnes \& Brockington 2003) along these gradients.
In the northern hemisphere, Petersen (1913) and Thorson (1957), pioneers in marine benthic ecology, compared patterns in shelf communities and showed that assemblages in different areas are seldom similar even when bottom type conditions are identical (Rosenberg 2001). In the southern hemisphere, Arntz \& Ríos (1999) summarised studies of different authors comparing the Magellan versus the Weddell Sea shelves, with special focus on ecological and evolutionary relations by describing distinct differences in species composition and community structure between these ecosystems. For example, a quantitative study in shallow waters performed in the northernmost part of the Magellan region yielded 38 species belonging to 24 families, with Nereidae and Orbiniidae being the 
most speciose families (Cañete et al. 1999). Gambi \& Mariani (1999) archived 119 polychaete species belonging to 34 families from the Straits of Magellan, and identified Syllidae and Ampharetidae as the most speciose families. In both studies, more than $50 \%$ of the species were common to the Magellan and Antarctic areas. The latter report suggests that no major differences between polychaete assemblages on either side of the Drake Passage exist. However, the reliability of species identification for polychaete assemblages and their quantitative attributes requires improvement.

The aims of the present study are (1) to provide a detailed description of shelf polychaete assemblages in the Magellan region and the high Antarctic Weddell Sea based on quantitative samples, and (2) to use biodiversity and density values to elucidate potential faunistic and zoogeographical links of the polychaete assemblages between the Magellan and the Antarctic Weddell Sea shelves.

\section{MATERIALS AND METHODS}

Study areas. The biogeographic Magellan region sensu Camus (2001) extends from about 42 to $55^{\circ} \mathrm{S}$ on the western coastal shelf of South America (Strub et al. 1998). The shelf has a mean width of $6.54 \mathrm{~km}$ (Gallardo 1984), whereas the Atlantic shelf extends to a width of about $850 \mathrm{~km}$ at $51^{\circ} \mathrm{S}$ (Piccolo 1998). Successive glaciation periods have structured the west coast with more than 200 fjords and channels (Syvitski et al. 1987), with water depths frequently less than $150 \mathrm{~m}$, and maximum depths of around $1050 \mathrm{~m}$. Sediments are mostly characterised by silt and clay, but coarser sediments such as pebbles and biogenic deposits from molluscs and barnacles are also present (Brambati et al. 1991). Three permanent ice fields exist: Campo de Hielo Norte (46 to $47^{\circ} \mathrm{S}$ ), Campo de Hielo Sur (48 to $\left.52^{\circ} \mathrm{S}\right)$ and the Darwin mountain range $\left(54\right.$ to $55^{\circ} \mathrm{S}$, Naruse \& Aniya 1992). The hydrographic regime is characterised by strong freshwater input due to high precipitation and concomitant runoff, producing a strong and shallow pycnocline (Dávila et al. 2002).

A mosaic of diverse soft-bottom habitats exists in the Magellan region (Arntz 1999). Taxa such as ascidians, brittle stars, decapods and brachiopods dominate the megafauna (Gutt et al. 1999), whereas polychaetes, amphipods and bivalves contribute considerably to the macrofauna (Gerdes \& Montiel 1999, Montiel et al. 2001).

The Weddell Sea stations are located on the SE shelf $\left(71^{\circ} \mathrm{S}, 10^{\circ} \mathrm{W} ; 71^{\circ} \mathrm{S}, 12^{\circ} \mathrm{W}\right)$. Due to the continent's ice cover, the shelf's depth is down to $800 \mathrm{~m}$ (Teixidó et al. 2002). The Weddell Sea shelf has a width range of between 10 and $40 \mathrm{~km}$, although a maximum of $90 \mathrm{~km}$ can be observed (Camarck \& Foster 1975). Near-bottom water temperatures are rather constant with values between -1.7 and $-1.9^{\circ} \mathrm{C}$, apart from common but unpredictable 'Warm Deep Water' intrusions, which may occasionally increase temperatures to $0.5^{\circ} \mathrm{C}$ (Gerdes et al. 1992). The sediment is dominated by sand, gravel and biogenic substrates (sponge and bryozoan debris), with numerous drop stones in between being transported by the continental ice sheet.

During winter, the sea ice covers a maximum of almost $20 \times 10^{6} \mathrm{~km}^{2}$ of the Antarctic Ocean. In austral summer, the coverage is reduced to less than $4 \times$ $10^{6} \mathrm{~km}^{2}$ (Eicken 1992). Along the SE Weddell Sea shelf, icebergs originating from the shelf ice often run aground and affect benthos communities down to about $300 \mathrm{~m}$ water depth. Due to this disturbance, the community structure of the Weddell Sea shelf benthos is the result of a combination of a rather constant temperature regime and considerable disturbance mainly by icebergs, all with implications for the function and structure of benthic communities (Piepenburg et al. 2002, Teixidó et al. 2002, Gerdes et al. 2003, Knust et al. 2003).

Sampling. Samples in the Magellan region (MR) were collected during 3 expeditions: (1) the Joint Chilean-German-Italian Magellan Campaign with RV 'Victor Hensen' in 1994 provided samples from stations in the Strait of Magellan and the Beagle Channel, (2) the Cimar-Fiordo II Expedition with RV 'Vidal Gormaz' in 1996 provided additional samples from the South Patagonian Icefield ( 47 to $53^{\circ} \mathrm{S}$ ) and (3) during the expedition ANT XIII/4 with RV 'Polarstern' in 1996, more samples were collected on the continental shelf and slope of the eastern entrance of the Beagle Channel $\left(55^{\circ} \mathrm{S}\right)$. The high Weddell Sea shelf samples (WS) were collected during expeditions ANT XV/3 and ANT XVII/3 with RV 'Polarstern' in 1998 and 2000, respectively (Fig. 1).

A total of 257 cores from 59 stations were collected with a multibox corer (Gerdes 1990) and a Reineck box corer (Reineck 1958). In MR, 41 stations (171 cores) were sampled and 18 stations (86 cores) in WS. The total area sampled was $4.3 \mathrm{~m}^{2}$ in MR and $2.1 \mathrm{~m}^{2}$ in WS. The mean depths at the MR and WS stations were 254 and $263 \mathrm{~m}$, respectively (Table 1 ). The macrofauna was sieved through $0.5 \mathrm{~mm}$ mesh, sorted and fixed in $4 \%$ buffered formaldehyde seawater solution prior to counting and identification of all polychaetes to species level.

Data processing. For comparison of the polychaete assemblages, we used the following attributes: (1) density (ind. $\mathrm{m}^{-2}$ ) per station, (2) dominance of species (\%), (3) trophic guild, (4) species composition, (5) diversity $\left(\exp H^{\prime}\right)$ and (6) evenness $(J)$. Additionally, point spe- 
cies richness and sample species richness $\left(\mathrm{SR}_{\mathrm{p}}\right.$ and $\mathrm{SR}_{\mathrm{S}}$, respectively) were calculated following the recommendations of Gray (2001a); $\mathrm{SR}_{\mathrm{p}}$ is the species richness of a single sampling unit (core) and $\mathrm{SR}_{\mathrm{S}}$ is the species richness of a number of sampling units from the same sampling location. According to Gray (2000), the heterogeneity of the species diversity $\left(\mathrm{HD}_{1}\right)$ was measured by the exponential form of the Shannon-Wiener index, based on $\log _{2}$ density data.

For the analysis of the trophic guild distribution patterns, each species was classified into a feeding category following the classification of Fauchald \& Jumars (1979) and Gaston (1983), modified according to Crame (1992); predators include carnivorous and omnivorous species, detritus feeders include all (sub-)surface deposit feeders and burrowing motile and sessile species, and suspension feeders were considered as a single group. According to this classification, the percentage of each trophic category per station was calculated and plotted in a triangular chart.

To elucidate any potential zoogeographic links between both sides of the Drake Passage, we compared data provided by the literature for the distribution and depth ranges of those polychaete species found in both areas under investigation. Species accumulation curves were calculated in order to compare the polychaete inventory among the different sample sizes from each region (Gray 1981, Lawrence \& Walters 1979) and to consider the high number of rare species in the samples (Cosson-Sarradin et al. 1998).

We established species-accumulation curves in the 2 regions according to the following procedure. The accumulation of the number of species $S$ with increasing number of individuals $N$ was computed using the EstimateS program (R. Colwell [2001] Online user's guide EstimateS at http://viceroy.eeb.uconn.edu/estimates). Estimate $S$ generates n data pairs of average $S$ and $N$ (averages refer to 100 randomised runs with replacement), where $\mathrm{n}$ is the number of samples considered ( $\mathrm{n}=171$ for $\mathrm{MR}_{i} \mathrm{n}=86$ for WS). Subsequently, a simple exponential model was fitted to these n data pairs of average $S$ and $N$.

Completeness of sampling of the species inventory was checked by computing the number of new species $S_{\mathrm{N}}$ to be expected if a further 1000 individuals had been collected:

$$
S_{\mathrm{N}}=\mathrm{a} \times N^{\mathrm{b}} \Leftrightarrow \ln \left(S_{\mathrm{N}}\right)=\ln (\mathrm{a})+(\mathrm{b} \times N)
$$

where $\mathrm{a}$ and $\mathrm{b}$ are regression parameter and coefficient, respectively. The smaller $S_{\mathrm{N}}$ is, the more comprehensively the inventory has been
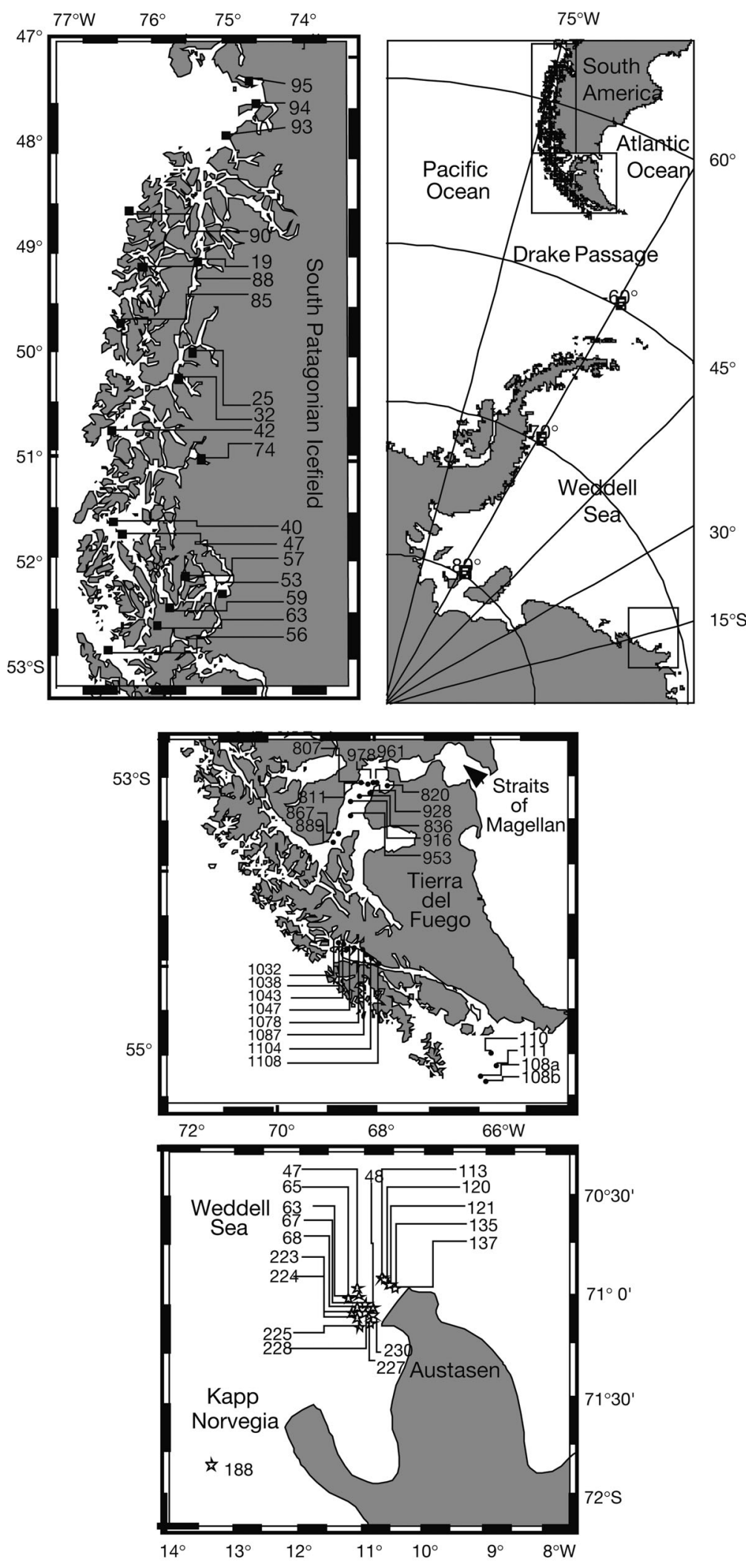

Fig. 1. Study area in the Magellan region (South America) and the Weddell Sea (Antarctica), with sampling locations indicated 
Table 1. Station data of sampling locations. BC: Reineck box corer; MG: multibox corer; VG: 'Vidal Gormaz'; VH: 'Victor Hensen'; PS: 'Polarstern'

\begin{tabular}{|c|c|c|c|c|c|c|c|c|c|c|}
\hline Code & Cruise & Leg & Stn & Gear & $\begin{array}{l}\text { No. of } \\
\text { cores }\end{array}$ & $\begin{array}{c}\text { Date } \\
\text { (d.mo.yr) }\end{array}$ & Location & Lat. & Long. & Depth (m) \\
\hline \multicolumn{11}{|c|}{ Magellan region } \\
\hline 1 & VG & Leg b & 95 & $\mathrm{BC}$ & 2 & 07.11 .1996 & B. San Quintín & $46^{\circ} 48.85$ & $74^{\circ} 26.9$ & 20 \\
\hline 2 & VG & Leg b & 94 & $\mathrm{BC}$ & 2 & 07.11 .1996 & Golfo de Penas & $46^{\circ} 57.50$ & $74^{\circ} 15.0$ & 92 \\
\hline 3 & VG & Leg b & 93 & $\mathrm{BC}$ & 2 & 07.11 .1996 & Golfo de Penas & $47^{\circ} 22.20$ & $74^{\circ} 38.7$ & 130 \\
\hline 4 & VG & Leg b & 90 & $\mathrm{BC}$ & 2 & 06.11 .1996 & C. Fallos & $48^{\circ} 23.40$ & $75^{\circ} 06.5$ & 550 \\
\hline 5 & VG & Leg a & 19 & $\mathrm{BC}$ & 2 & 20.10 .1996 & C. Messier & $48^{\circ} 39.10$ & $74^{\circ} 27.2$ & 410 \\
\hline 6 & VG & Leg $b$ & 88 & $\mathrm{BC}$ & 2 & 05.11 .1996 & C. Ladrilleros & $48^{\circ} 56.60$ & $75^{\circ} 02.0$ & 630 \\
\hline 7 & VG & Leg $b$ & 85 & $\mathrm{BC}$ & 2 & 04.11 .1996 & C. Picton & $49^{\circ} 28.90$ & $75^{\circ} 25.2$ & 98 \\
\hline 8 & VG & Leg a & 25 & $\mathrm{BC}$ & 2 & 21.10 .1996 & C. Ice & $49^{\circ} 33.60$ & $74^{\circ} 12.4$ & 538 \\
\hline 9 & VG & Leg a & 32 & $\mathrm{BC}$ & 2 & 24.10 .1996 & Seno Penguin & $49^{\circ} 54.29$ & $74^{\circ} 18.6$ & 711 \\
\hline 10 & VG & Leg a & 42 & $\mathrm{BC}$ & 2 & 25.10 .1996 & C. Concepción & $50^{\circ} 35.70$ & $75^{\circ} 04.5$ & 532 \\
\hline 11 & VG & Leg $b$ & 74 & $\mathrm{BC}$ & 2 & 02.11 .1996 & Estero Calvo & $50^{\circ} 37.90$ & $73^{\circ} 37.4$ & 385 \\
\hline 12 & VG & Leg a & 40 & $\mathrm{BC}$ & 2 & 24.10 .1996 & C. Concepción & $50^{\circ} 9.55$ & $74^{\circ} 42.1$ & 323 \\
\hline 13 & VG & Leg a & 47 & $\mathrm{BC}$ & 2 & 26.10 .1996 & Estrecho Nelson & $51^{\circ} 35.00$ & $74^{\circ} 31.0$ & 615 \\
\hline 14 & VG & Leg $b$ & 57 & $\mathrm{BC}$ & 2 & 31.10 .1996 & E. las Montañas & $51^{\circ} 49.00$ & $73^{\circ} 19.4$ & 136 \\
\hline 15 & VG & Leg a & 53 & $\mathrm{BC}$ & 2 & 27.10 .1996 & S.Ult.Esperanza & $51^{\circ} 54.30$ & $72^{\circ} 33.7$ & 32 \\
\hline 16 & VG & Leg $b$ & 59 & $\mathrm{BC}$ & 3 & 27.10 .1996 & C. Kirke & $52^{\circ} 10.30$ & $73^{\circ} 21.7$ & 238 \\
\hline 17 & VG & Leg $b$ & 63 & $\mathrm{BC}$ & 2 & 31.10 .1996 & C. Smith & $52^{\circ} 26.40$ & $73^{\circ} 29.5$ & 175 \\
\hline 18 & VG & $\operatorname{Leg} b$ & 56 & $\mathrm{BC}$ & 2 & 30.10 .1996 & C. Kirke & $52^{\circ} 5.66$ & $73^{\circ} 07.5$ & 136 \\
\hline 19 & $\mathrm{VH}$ & $\operatorname{Leg} 1$ & 928 & MG & 6 & 28.10 .1994 & Magellan Straits & $52^{\circ} 57.8$ & $70^{\circ} 25.6$ & 44 \\
\hline 20 & $\mathrm{VH}$ & $\operatorname{Leg} 1$ & 961 & $\mathrm{MG}$ & 6 & 31.10 .1994 & Magellan Straits & $52^{\circ} 57.9$ & $70^{\circ} 43.5$ & 38 \\
\hline 21 & $\mathrm{VH}$ & $\operatorname{Leg} 1$ & 807 & $\mathrm{MG}$ & 6 & 18.10 .1994 & Magellan Straits & $52^{\circ} 57.9$ & $70^{\circ} 47.2$ & 14 \\
\hline $\begin{array}{l}21 \\
22\end{array}$ & $\mathrm{VH}$ & $\operatorname{Leg} 1$ & 811 & MG & 6 & 18.10 .1994 & Magellan Straits & $52^{\circ} 58.4$ & $70^{\circ} 42.2$ & 119 \\
\hline 23 & $\mathrm{VH}$ & $\operatorname{Leg} 1$ & 953 & MG & 8 & 31.10 .1994 & Magellan Straits & $52^{\circ} 59.8$ & $70^{\circ} 33.0$ & 80 \\
\hline 24 & $\mathrm{VH}$ & Leg 1 & 820 & MG & 8 & 18.10 .1994 & Magellan Straits & $53^{\circ} 02.5$ & $70^{\circ} 17.1$ & 8 \\
\hline 25 & $\mathrm{VH}$ & Leg 1 & 836 & MG & 8 & 23.10 .1994 & Magellan Straits & $53^{\circ} 08.4$ & $70^{\circ} 38.4$ & 120 \\
\hline 26 & VH & Leg 1 & 916 & MG & 8 & 28.10 .1994 & Magellan Straits & $53^{\circ} 10.2$ & $70^{\circ} 52.3$ & 26 \\
\hline 27 & VH & Leg 1 & 978 & MG & 8 & 01.11 .1994 & Magellan Straits & $53^{\circ} 32.7$ & $70^{\circ} 39.3$ & 459 \\
\hline 28 & VH & Leg 1 & 867 & MG & 8 & 25.10 .1994 & Magellan Straits & $53^{\circ} 40.7$ & $70^{\circ} 54.6$ & 445 \\
\hline 29 & $\mathrm{VH}$ & Leg 1 & 889 & $\mathrm{MG}$ & 5 & 26.10 .1994 & Magellan Straits & $53^{\circ} 42.7$ & $70^{\circ} 57.3$ & 114 \\
\hline 30 & VH & Leg 2 & 1047 & MG & 4 & 04.11 .1994 & Beagle C & $54^{\circ} 50.1$ & $69^{\circ} 56.6$ & 101 \\
\hline 31 & VH & Leg 2 & 1038 & $\mathrm{MG}$ & 6 & 04.11 .1994 & Beagle C & $54^{\circ} 50.9$ & $69^{\circ} 55.7$ & 38 \\
\hline 32 & VH & Leg 2 & 1043 & MG & 4 & 04.11 .1994 & Beagle C & $54^{\circ} 51.9$ & $69^{\circ} 55.2$ & 216 \\
\hline 33 & VH & Leg 2 & 1032 & MG & 8 & 04.11 .1994 & Beagle C & $54^{\circ} 52.7$ & $69^{\circ} 54.5$ & 330 \\
\hline 34 & VH & Leg 2 & 1104 & MG & 7 & 06.11 .1994 & Beagle C & $54^{\circ} 53.1$ & $69^{\circ} 30.3$ & 91 \\
\hline 35 & VH & Leg 2 & 1078 & $\mathrm{MG}$ & 8 & 05.11 .1994 & Beagle C & $54^{\circ} 53.5$ & $69^{\circ} 31.0$ & 348 \\
\hline 36 & VH & Leg 2 & 1108 & MG & 6 & 06.11 .1994 & Beagle C & $54^{\circ} 55.0$ & $69^{\circ} 19.5$ & 100 \\
\hline 37 & $\mathrm{VH}$ & Leg 2 & 1087 & MG & 8 & 05.11 .1994 & Beagle C & $54^{\circ} 55.3$ & $69^{\circ} 19.7$ & 169 \\
\hline 38 & PS & $\mathrm{XIII} / 4$ & 110 & MG & 7 & 17.05 .1996 & Continental shelf & $55^{\circ} 26.1$ & $66^{\circ} 15.5$ & 102 \\
\hline 39 & PS & $\mathrm{XIII} / 4$ & 111 & MG & 6 & 17.05 .1996 & Continental slope & $55^{\circ} 28.8$ & $66^{\circ} 04.4$ & 1162 \\
\hline 40 & PS & $\mathrm{XIII} / 4$ & 108 & MG & 4 & 16.05 .1996 & Continental shelf & $55^{\circ} 44.1$ & $66^{\circ} 16.7$ & 202 \\
\hline 41 & PS & $\mathrm{XIII} / 4$ & 108 & MG & 3 & 16.05 .1996 & Continental shelf & $55^{\circ} 44.1$ & $66^{\circ} 16.7$ & 204 \\
\hline \multicolumn{11}{|c|}{ Weddell Sea shelf } \\
\hline 42 & PS & $\mathrm{XV} / 3$ & 227 & MG & 6 & 20.02 .1998 & Kapp Norvegia & $70^{\circ} 49.5$ & $10^{\circ} 38.5$ & 360 \\
\hline 43 & PS & $\mathrm{XV} / 3$ & 224 & MG & 7 & 19.02 .1998 & Kapp Norvegia & $70^{\circ} 49.8$ & $10^{\circ} 34.4$ & 279 \\
\hline 44 & PS & $\mathrm{XV} / 3$ & 228 & MG & 6 & 20.02 .1998 & Kapp Norvegia & $70^{\circ} 49.8$ & $10^{\circ} 37.9$ & 284 \\
\hline 45 & PS & $\mathrm{XV} / 3$ & 67 & MG & 7 & 01.02 .1998 & Kapp Norvegia & $70^{\circ} 49.9$ & $10^{\circ} 36.7$ & 293 \\
\hline 46 & PS & $\mathrm{XVII} / 3$ & 113 & MG & 4 & 06.04 .2000 & Austasen & $70^{\circ} 49.9$ & $10^{\circ} 36.8$ & 275 \\
\hline 47 & PS & $\mathrm{XV} / 3$ & 225 & MG & 6 & 19.02 .1998 & Kapp Norvegia & $70^{\circ} 50.1$ & $10^{\circ} 35.2$ & 276 \\
\hline 48 & PS & $\mathrm{XV} / 3$ & 223 & MG & 3 & 19.02 .1998 & Kapp Norvegia & $70^{\circ} 50.2$ & $10^{\circ} 34.9$ & 273 \\
\hline 49 & PS & $\mathrm{XV} / 3$ & 68 & $\mathrm{MG}$ & 3 & 01.02 .1998 & Kapp Norvegia & $70^{\circ} 50.3$ & $10^{\circ} 38.1$ & 269 \\
\hline 50 & PS & $\mathrm{XV} / 3$ & 230 & $\mathrm{MG}$ & 7 & 20.02 .1998 & Kapp Norvegia & $70^{\circ} 50.8$ & $10^{\circ} 32.2$ & 229 \\
\hline 51 & PS & XVII/3 & 135 & MG & 2 & 10.04 .2000 & Austasen & $70^{\circ} 50.2$ & $10^{\circ} 34.5$ & 256 \\
\hline 52 & PS & XVII/3 & 137 & MG & 3 & 10.04 .2000 & Austasen & $70^{\circ} 50.2$ & $10^{\circ} 34.7$ & 272 \\
\hline 53 & PS & XVII/3 & 120 & MG & 4 & 08.04 .2000 & Austasen & $70^{\circ} 50.3$ & $10^{\circ} 35.0$ & 271 \\
\hline 54 & PS & $\mathrm{XV} / 3$ & 63 & MG & 4 & 31.01 .1998 & Kapp Norvegia & $70^{\circ} 51.8$ & $10^{\circ} 34.4$ & 234 \\
\hline 55 & PS & $\mathrm{XV} / 3$ & 65 & MG & 2 & 30.01 .1998 & Kapp Norvegia & $70^{\circ} 51.9$ & $10^{\circ} 34.2$ & 227 \\
\hline 56 & PS & $\mathrm{XV} / 3$ & 47 & MG & 7 & 30.01 .1998 & Kapp Norvegia & $70^{\circ} 52.2$ & $10^{\circ} 29.3$ & 243 \\
\hline 57 & PS & $\mathrm{XV} / 3$ & 48 & MG & 5 & 30.01 .1998 & Kapp Norvegia & $70^{\circ} 52.2$ & $10^{\circ} 29.3$ & 245 \\
\hline 58 & PS & $\mathrm{XVII} / 3$ & 121 & MG & 5 & 08.10 .2000 & Austasen & $70^{\circ} 53.6$ & $10^{\circ} 34.2$ & 249 \\
\hline 59 & PS & $\mathrm{XV} / 3$ & 188 & MG & 5 & 15.02 .1998 & Kapp Norvegia & $71^{\circ} 31.5$ & $13^{\circ} 30.6$ & 225 \\
\hline
\end{tabular}




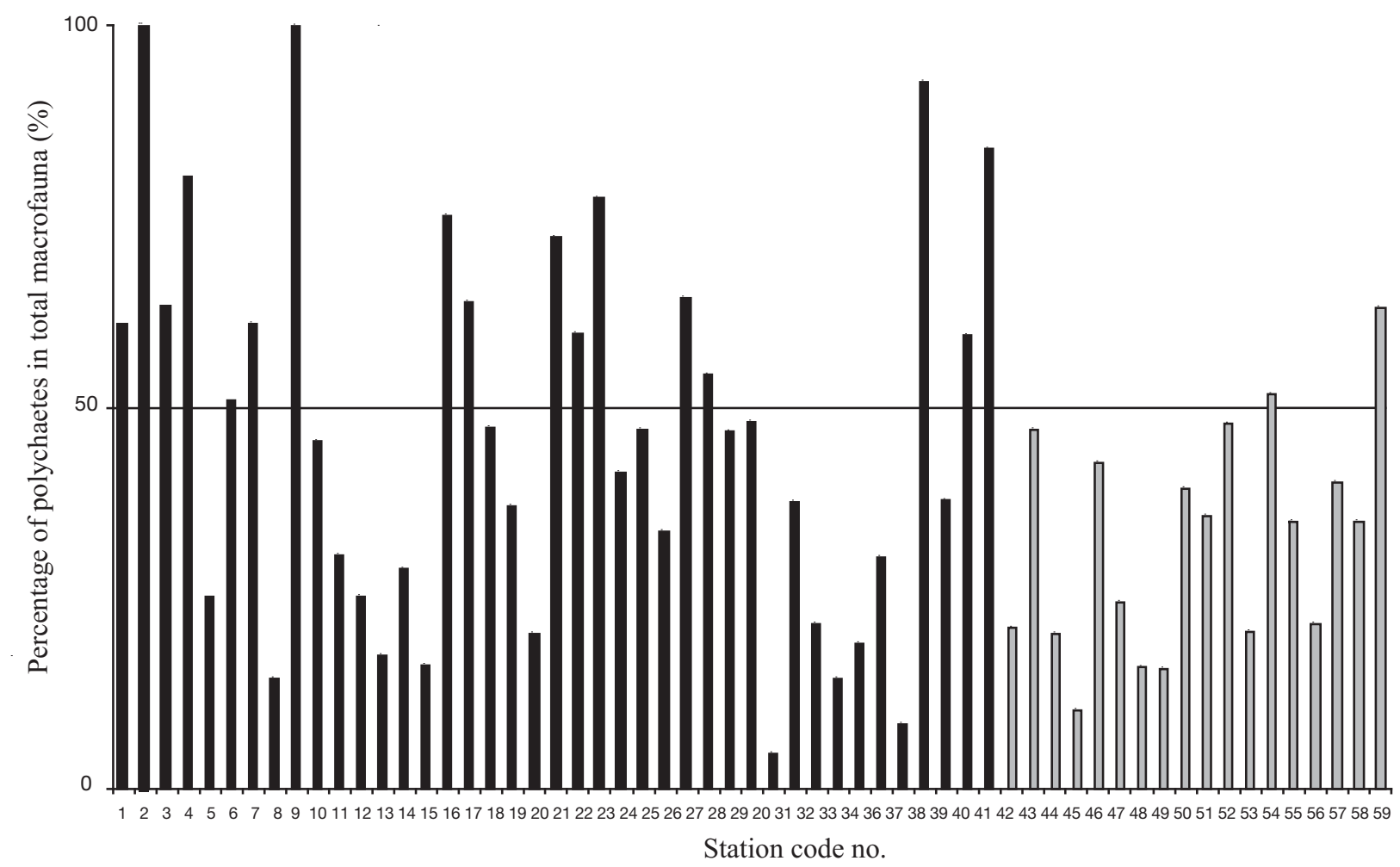

Fig. 2. Comparison of the percentage of polychaete individuals in the total macrofauna obtained at each station (in the Magellan region, $\mathrm{n}=5508$ ind.; in Weddell Sea, $\mathrm{n}=4225$ ind.). All stations plotted are arranged in a $\mathrm{N}-\mathrm{S}$ direction; for code number see Table 1. Magellan region: black bars; Weddell Sea: grey bars

performed; i.e., in this case, more specimens $N$ are included.

An objective and comparable measure of species richness was derived by determining the points of equal slope in both species-individual curves, i.e. the number of individuals $N$ at which the addition of a further $X$ individuals would result in exactly 1 additional species, $P_{X, 1}$ :

$$
S_{\mathrm{N}+X}-S_{\mathrm{N}} \leq 1
$$

This equation had to be solved iteratively by minimising:

$$
\operatorname{abs}\left[N-(N+X)^{\mathrm{b}}-1 / \mathrm{a}\right]^{1 / \mathrm{b}}
$$

$N$ and the corresponding $S$ which are computed from the exponential model defining the point of equal slope:

$$
P_{X, 1} \approx\left\{N_{;} S\right\}
$$

Confidence limits for the true mean of $S_{\mathrm{N}}$ were computed according to standard linear regression procedures (Draper \& Smith 1981).

Multidimensional scaling ordination (MDS), based on 4 th root-transformed density values (Bray-Curtis similarity coefficients) was performed to identify differences between MR and WS. The multivariate statis- tical methods of classification and ordination used the software package PRIMER Version 5.2.1 (Clark \& Warwick 1994). The differences between the remaining community parameters were tested with a MannWhitney U-test (Zar 1999).

\section{RESULTS}

\section{Family composition}

A total of 2974 polychaete individuals were collected; 1668 in MR and 1306 in WS. The percentage of polychaetes in the total macrofauna per station varied between 4.5 and $100 \%$ in MR, and between 30 and $60 \%$ in WS (Fig. 2).

Of the 334 species belonging to 179 genera, 199 species were found in MR and 163 in WS; 28 species and 58 genera occurred in both regions. Of the 44 families, 37 were found in MR and 36 in WS. Thirtytwo families were common in both regions while Onuphidae, Cossuridae, Oenonidae, Eunicidae, Goniadidae, Sigalionidae, Magellonidae and Sternaspidae were restricted to $\mathrm{MR}$, and Lacydoniidae, Chrysopetalidae, Polygordiidae and Spintheridae were only recorded in WS. 


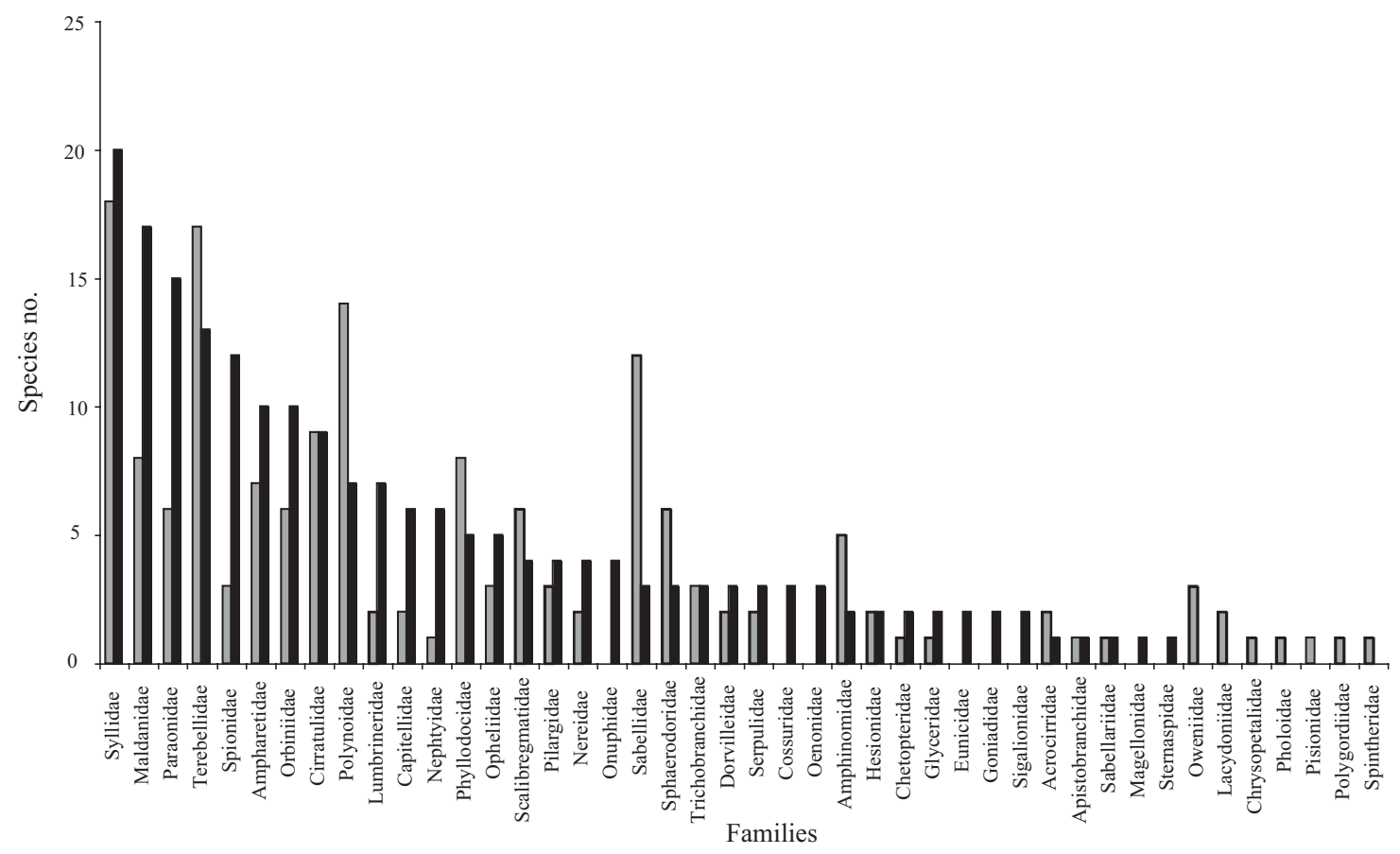

Fig. 3. Comparison of the total species number per polychaete family obtained from the study areas. Magellan region: black bars; Weddell Sea: grey bars

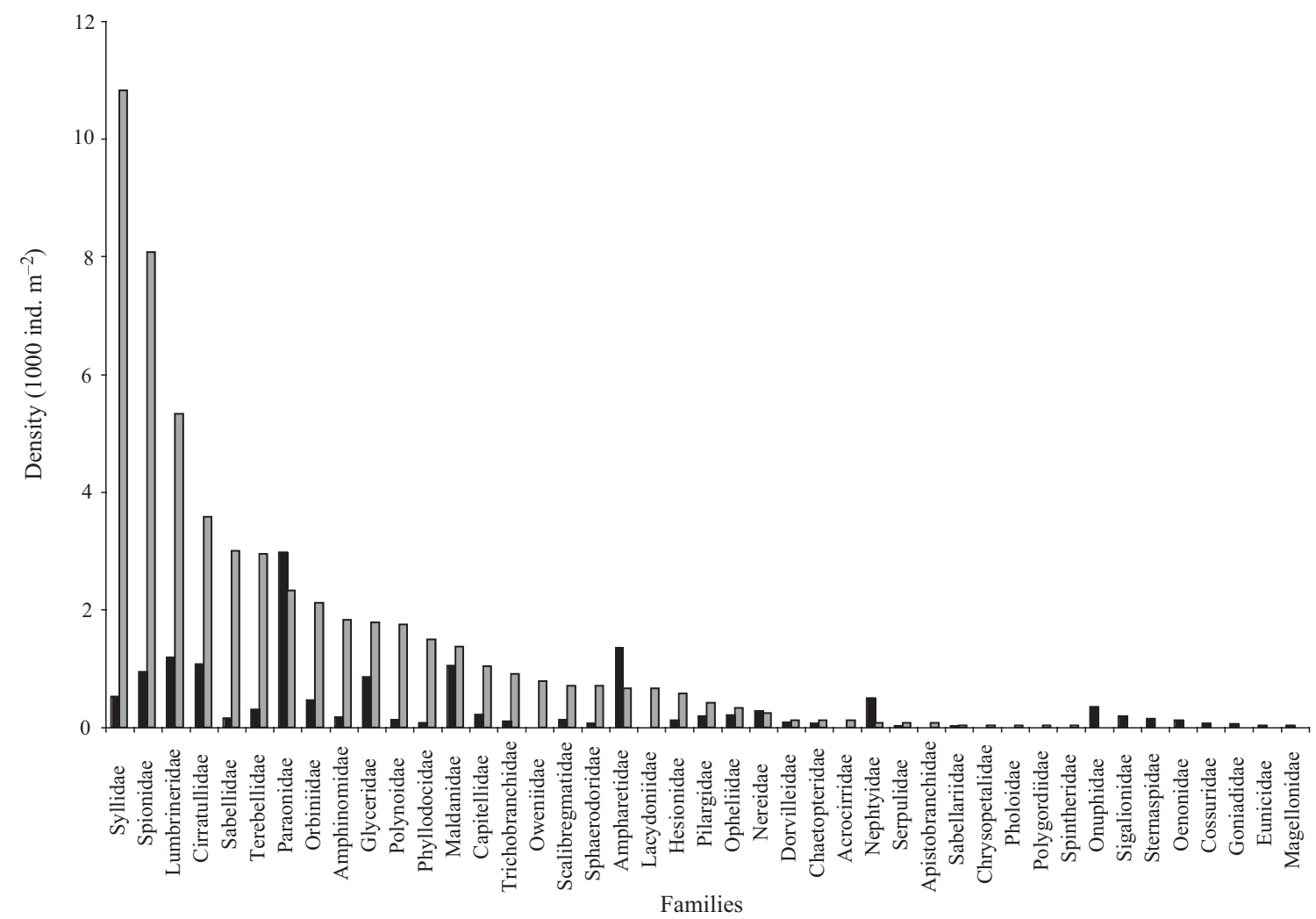

Fig. 4. Comparison of total density values (ind. $\mathrm{m}^{-2}$ ) per family obtained in the study areas. Magellan region: black bars; Weddell Sea: grey bars 


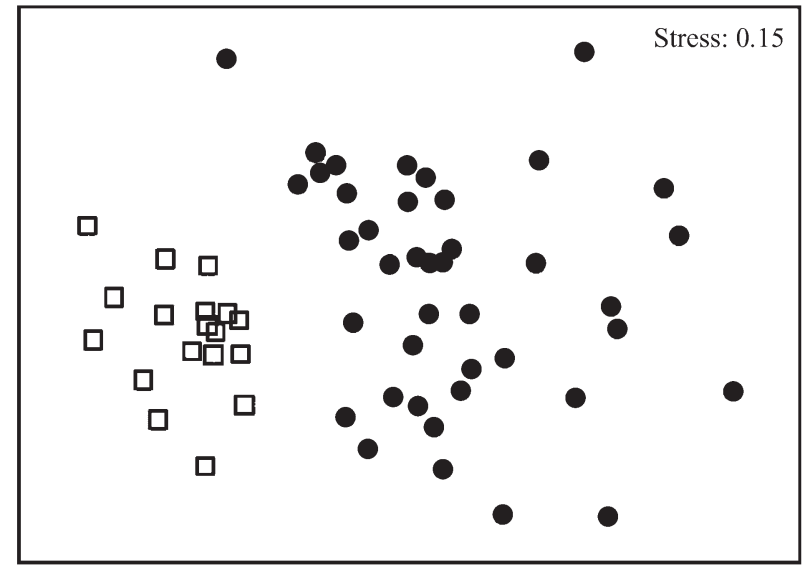

Fig. 5. MDS plot for $\sqrt{ } \sqrt{ }$ transformation of the mean density data using group average linkage on Bray-Curtis similarities for differences between study areas. Magellan region: Weddell Sea: $\square$

The most speciose families were Syllidae $10 \%$ of all polychaete species), Maldanidae (9\%) and Paraonidae $(7 \%)$ in $\mathrm{MR}$, and Terebellidae $(12 \%)$, Syllidae $(11 \%)$ and Polynoidae (9\%) in WS (Fig. 3). The most abundant families were Paraonidae (21\% of all individuals), Ampharetidae (9\%) and Lumbrineridae (8\%) in MR, and Syllidae (20\%), Spionidae (15\%) and Lumbrineridae $(10 \%)$ in WS (Fig. 4).

\section{Structure of the polychaete species assemblage}

The result of the MDS (stress of 0.15) clearly discriminates between MR and WS (Fig. 5). A Mann-Whitney $U$-test was carried out separately and confirmed this result, showing that the mean densities per station (see Fig. 6a) were significantly higher $(\mathrm{n}=257, U$-test $=$ 5873, $\mathrm{p}=0.0085)$ in WS (mean $=582 \pm 448)$ than in MR $($ mean $=352 \pm 319 ;$ Table 2$)$.

The species abundance distribution in both regions showed a high number of species represented by only 1 specimen (Fig. 7a,b). This led to high values of evenness (Table 2) and low dominance values on either side of the Drake Passage. In MR, the maximum dominance value at the species level was $9 \%$ of the total density for Aricidea strelzovi, and $50 \%$ cumulative dominance was achieved with 14 species in MR (Table 3). The remaining 185 species only contributed between 0.1 and $2 \%$ per species. In WS, Spiophanes tcherniai accounted for the maximum dominance value $(10 \%)$ at the species level, and 14 species made up $54 \%$ of the cumulative dominance (Table 3). The remaining 149 species only reached percentages between 0.1 and $2 \%$ per species.

Detritus feeders (57\% of all individuals) constituted the dominant trophic guild in both regions, followed by predators (38\%) and suspension feeders (5\%). Suspension feeders accounted for only $17 \%$ of species at the MR stations, whereas detritus feeders and predators prevailed at all stations. In contrast, at most of the WS stations, all 3 trophic guilds were present (Fig. 8). Among the detritus feeders in MR, the highest numbers of individuals were those of Aricidea strelzovi, A. pisanoi and Prionospio orensanzi; the predator guild was represented by Glycera capitata and Aglaophamus peruana; and the suspension feeders consisted mainly of Hypsicomus phaeotaenia.

In WS, Spiophanes tcherniai contributed the highest individual number of detritus feeders; the predator guild was mainly represented by Syllis spongiphila and Glycera kerguelensis; and among the suspension feeders, Jasmineira crumenifera, Euchone pallida and Galathowenia wilsoni were dominant.

Mean point species richness $\left(\mathrm{SR}_{\mathrm{si}}\right.$ Fig. $\left.6 \mathrm{~b}\right)$ and heterogeneity diversity $\left(\mathrm{HD}_{1}\right.$; Fig. 9) showed significantly lower values at the MR than at the WS stations ( $U$-test = 5336.0 and 5207.0, respectively; $\mathrm{p}<0.05$; Table 2). Evenness values of cores containing more than 1 individual per species were not significantly different $(U$ test $=5471.0 ; \mathrm{p}>0.05)$ between the MR and WS stations (Table 2).

The randomised cumulative species plots (Fig. 10) for both regions showed significant differences. The shape of the curves did not reach an asymptote in either region, because the individual numbers were low and both species' inventories were not considered completely.

Twenty-eight species were common to both regions (Table 4). Four species were cosmopolitans; Artacama proboscidea had a bipolar distribution. Ten species showed a circumpolar distribution around the (sub-) Antarctic; e.g. Augeneria tentaculata. The remaining species occurred from low to high latitudes; e.g. Aricidea strelzovi and Sphaerodoropsis parva along the Chilean coast through the Drake Passage into the high Weddell Sea. Concerning the depth distribution of these species, $57 \%$ showed a eurybathic distribution or a wide depth range, whereas the remaining species showed stenobathic distribution patterns.

\section{DISCUSSION}

This study improves and updates the precision of the distribution limits of polychaete species on either side of the Drake Passage, and presents empirical ecological data from 2 research areas in the Southern Ocean, where taxonomic information is still scarce and, as Clarke \& Johnston (2003) concluded, a revision of polychaetes is urgently needed. 

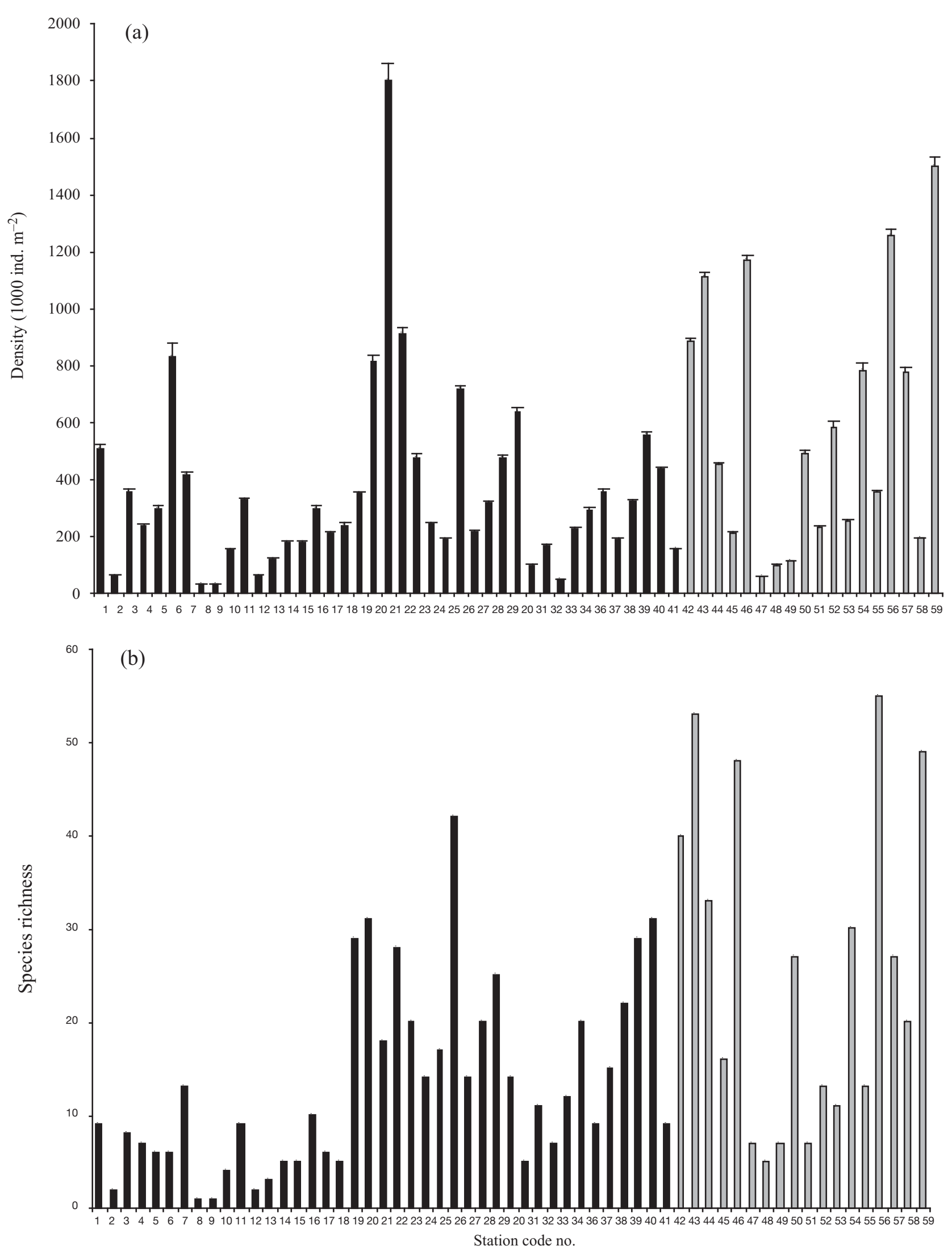

Fig. 6. Plot showing (a) mean density and (b) species richness $\left(\mathrm{SR}_{\mathrm{s}}\right)$ per station in the study areas. Magellan region: black bars; Weddell Sea: grey bars. Error bars are SD 
Table 2. Mann-Whitney $U$-test for differences in density, species richness, diversity and evenness values (means $\pm \mathrm{SD}$ ) between the Magellan region (MR) and Weddell Sea (WS) areas at $\alpha=0.05$. Significant $p$-values are shown in bold. The sample numbers for evenness values were 145 for MR and 77 for WS

\begin{tabular}{|c|c|c|c|c|}
\hline & $\begin{array}{c}\text { MR } \\
(\mathrm{n}=171)\end{array}$ & $\begin{array}{c}\text { WS } N \\
(\mathrm{n}=86)\end{array}$ & $\begin{array}{c}\text { Mann-Whitney } \\
\text { U-test }\end{array}$ & $\mathrm{p}$-values \\
\hline Mean density (ind. $\mathrm{m}^{-2}$ ) & $352 \pm 319$ & $582 \pm 448$ & 5873.0 & 0.0085 \\
\hline Mean point species richness $\left(\mathrm{SR}_{\mathrm{p}}\right)$ & $5.0 \pm 3.9$ & $8.9 \pm 7.0$ & 5336.0 & 0.0003 \\
\hline Heterogeneity diversity $\left(\mathrm{HD}_{1}\right)$ & $4.7 \pm 3.0$ & $7.5 \pm 5.4$ & 5207.0 & 0.0001 \\
\hline Evenness $\left(J^{\prime}\right)$ & $0.7 \pm 0.3$ & $0.9 \pm 0.04$ & 5471.0 & 0.8056 \\
\hline
\end{tabular}

description of polychaete assemblages at the species level on either side of the Drake Passage based on the same sampling methods, enabling us to compare data from these ecosystems which remained closely together for a considerable period of time and became separated rather late during the break-up of Gondwana some 20 to 30 million yr ago.

Our data suggest that today both areas differ significantly in terms of polychaete density, diversity, species

Inventories of polychaete assemblages at the species level in WS and MR waters have been little studied in the last $30 \mathrm{yr}$. The lack of descriptions of assemblages up to now complicates the establishment and comparison of polychaete assemblage patterns in both areas. This study provides the most comprehensive
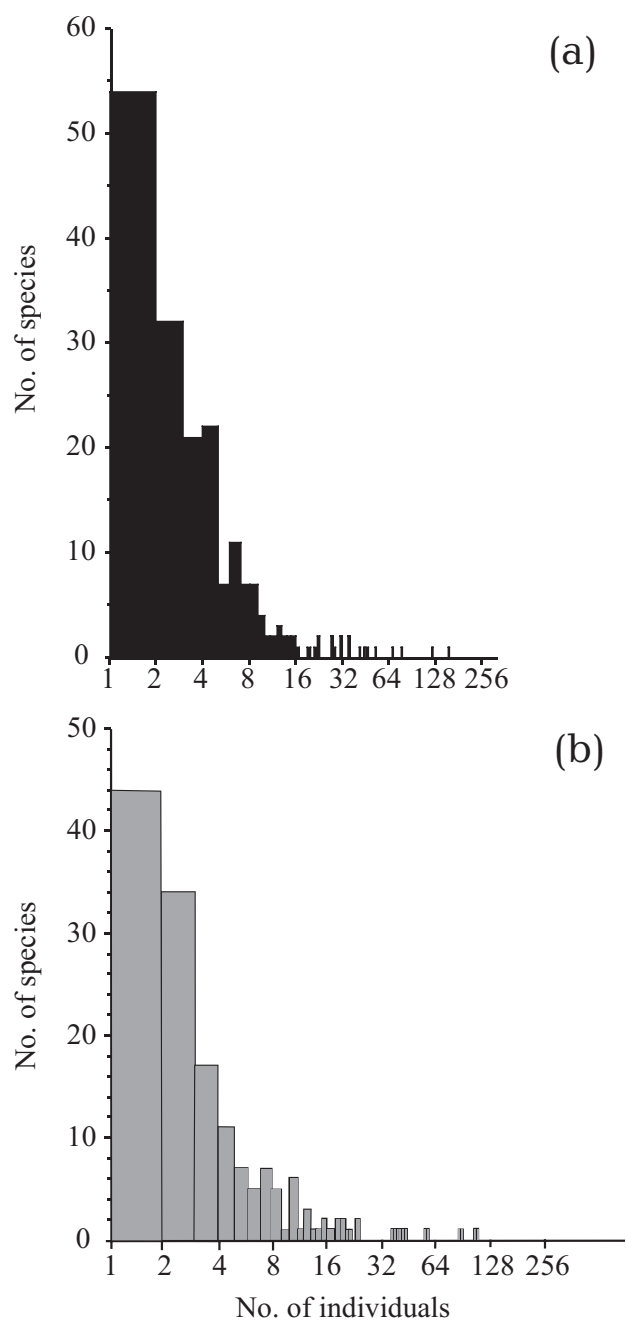

Fig. 7. Species abundance distribution in the (a) Magellan region and (b) Weddell Sea (expressed on a $\log _{2}$ scale) richness and affiliation to different trophic guilds. In both regions, the assemblages are characterised by high variability in these attributes; this might be explained by the heterogeneity of local environmental properties, which are often shaped by ice. On the WS shelf, benthic communities are disturbed directly by grounding ice bergs, while in MR, effects are due to melting glaciers, which might change the hydrographic regime and sedimentation processes, thus indirectly affecting benthic assemblages.

Table 3. Polychaete dominance patterns in the Magellan region and Weddell Sea

\begin{tabular}{|c|c|c|c|}
\hline Species MR & $\begin{array}{l}\text { Density } \\
\text { (ind. } \mathrm{m}^{-2} \text { ) }\end{array}$ & $\begin{array}{c}\text { Dominance } \\
(\%)\end{array}$ & $\begin{array}{l}\text { Cumulative } \\
\text { dominance }\end{array}$ \\
\hline \multicolumn{4}{|l|}{ Magellan region } \\
\hline Aricidea strelzovi & 6613 & 9 & 9 \\
\hline Glycera capitata & 5119 & 7 & 16 \\
\hline Aricidea pisanoi & 3209 & 4 & 21 \\
\hline Prionospio orensanzi & 3125 & 4 & 25 \\
\hline Levinsenia gracilis & 2845 & 4 & 29 \\
\hline Monticellina sp. & 2184 & 3 & 32 \\
\hline Chaetozone sp. 2 & 1917 & 3 & 35 \\
\hline Lumbrineris magelhaensis & 1833 & 3 & 37 \\
\hline Leitoscoloplos sp. & 1708 & 2 & 39 \\
\hline Ampharete kergulensis & 1617 & 2 & 42 \\
\hline Melinna cristata & 1565 & 2 & 44 \\
\hline Aglaophamus peruana & 1494 & 2 & 46 \\
\hline Abyssoninoe abyssorum & 1327 & 2 & 48 \\
\hline Ninoe falklandica & 1308 & 2 & 50 \\
\hline \multicolumn{4}{|l|}{ Weddell Sea } \\
\hline Spiophanes tcherniai & 5459 & 10 & 10 \\
\hline Syllis spongiphila & 4500 & 8 & 18 \\
\hline $\begin{array}{l}\text { Lumbrineris cf. } \\
\text { kerguelensis }\end{array}$ & 3750 & 7 & 25 \\
\hline Laonice weddellia & 2542 & 5 & 30 \\
\hline Cirrophorus brevicirratus & 1833 & 3 & 33 \\
\hline Glycera kerguelensis & 1792 & 3 & 37 \\
\hline Chaetozone sp. 3 & $170 a 8$ & 3 & 40 \\
\hline Sphaerosyllis antarctica & 1667 & 3 & 43 \\
\hline Augeneria tentaculata & 1583 & 3 & 46 \\
\hline Notomastus latericeus & 958 & 2 & 47 \\
\hline Scoloplos marginatus & 958 & 2 & 49 \\
\hline Jasmineira crumenifera & 875 & 2 & 51 \\
\hline Harmothoe spinosa & 833 & 2 & 52 \\
\hline Typosyllis armillaris & 792 & 1 & 54 \\
\hline
\end{tabular}




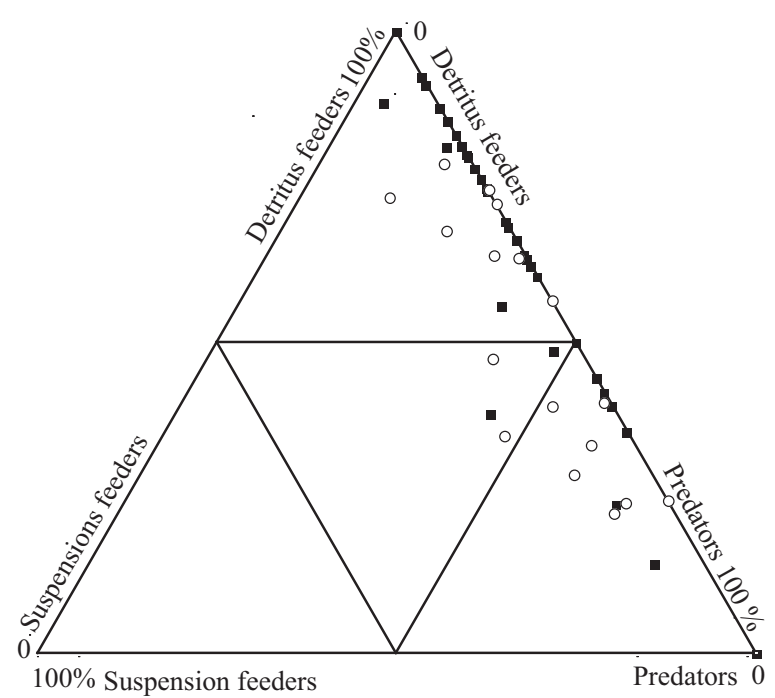

Fig. 8. Triangular chart showing polychaete feeding modes in the study areas. Values refer to percent per station in the Magellan region ( $\square$ ) and Weddell Sea (o) areas

The actual patterns derived from this study are based on 163 species and 36 families in WS, and 199 species and 37 families in MR. The latter figures represent the highest numbers of species/families reported up to now for the little studied MR. Maurer \& Williams (1988) reported 76 polychaete species belonging to 33 families for the Straits of Magellan, while Cañete et al. (1999) distinguished 38 species from 24 families in 39 corer samples from the northern border of MR. Bremec et al. (2000) found 119 polychaete species from 34 families in the Straits of Magellan and 36 species from 20 families on the eastern Patagonian shelf in their qualitative and quantitative samples.

Comparable quantitative information from the high Antarctic WS is also very scarce. Somewhat better is

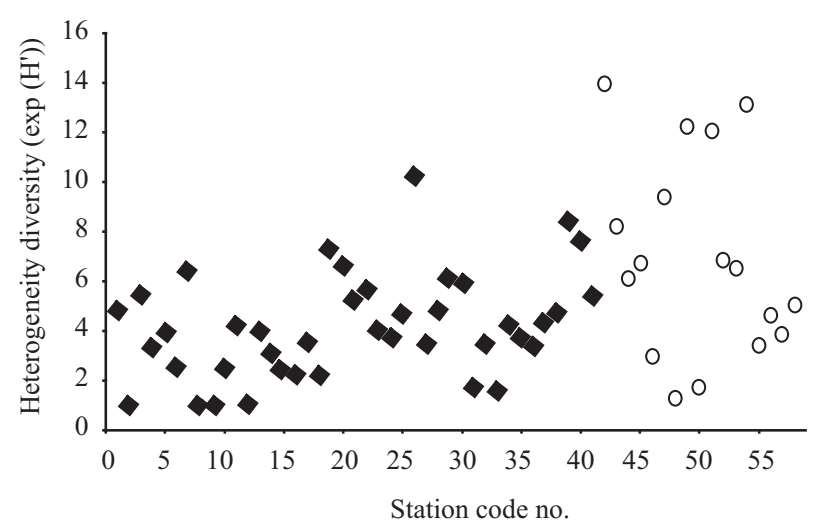

Fig. 9. Plot of $\mathrm{HD}_{1}$ per station through the studied areas, where $\mathrm{HD}_{1}=\exp \left(H^{\prime}\right)$. Magellan region: $\bullet$; Weddel Sea: 0

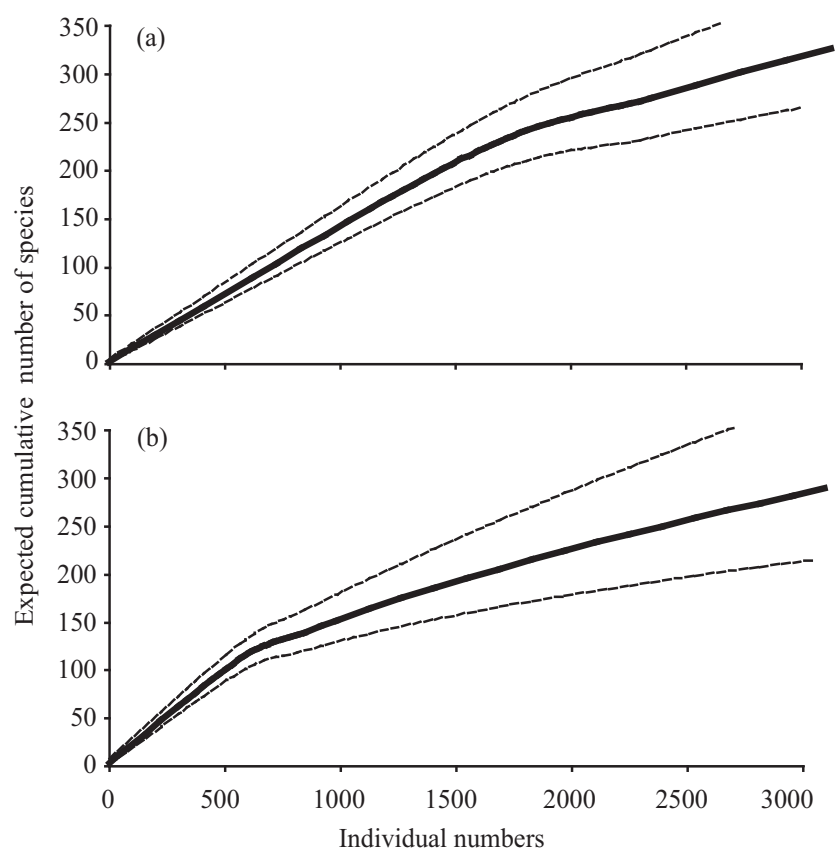

Fig. 10. Estimated cumulative species richness in the (a) Magellan region and (b) Weddell Sea using the EstimateS program (R. Colwell [2001] at http://viceroy.eeb.uconn.edu/estimates), with 50 randomisations and no replacement. --- = SD

the available information from the Subantarctic Islands and the Antarctic Peninsula. From the high Antarctic Weddell Sea, Hartman (1978) described 37 polychaete species with Cirratulidae and Maldanidae being the most speciose families from just 2 van Veen grab samples. Stiller (1996) reported 20 polynoid and 2 aphroditid species from the WS and Lazarev Sea shelves. Additional information from WS, reported by Hartman (1964, 1966), was obtained from qualitative sampling with towed gear.

Gallardo et al. (1988) reported 206 polychaete species from 26 families from the Subantarctic Greenwich Island. Terebellidae, Spionidae and Phyllodocidae were the most speciose families on sublittoral softbottoms at this location. Recently, San Martin et al. (2000) recorded 29 families with 89 species off Livingston Island, Deception Island and the South Shetland Islands; the most speciose families in their samples were Terebellidae, Syllidae and Maldanidae.

The species composition per family on the WS shelf resembles that reported by Clarke \& Johnston (2003) for waters south of the Polar Front. The most speciose families Syllidae and Terebellidae are represented most dominantly by Syllis spongiphila and Pista corrientis, respectively, whereas in MR, the most speciose families Syllidae, Maldanidae and Paranoidae were represented particularly by Typosyllis hyalina, Maldane sarsi and Aricidea strelzovi, respectively. 
Table 4. List of polychaete species occurring in both regions (Magellan region [MR] and Weddell Sea [WS] and their respective densities and bathymetric distribution patterns [D]). LaD: latitudinal distribution; CiP: circum (sub-)Antarctic; BiD: bipolar distribution; CoD: cosmopolitan distribution

\begin{tabular}{|c|c|c|c|c|}
\hline \multirow[t]{2}{*}{ Species } & \multicolumn{2}{|c|}{$\begin{array}{l}\text { Density } \\
\text { (ind. } \mathrm{m}^{-2} \text { ) }\end{array}$} & \multirow{2}{*}{$\begin{array}{c}\text { Depth } \\
(\mathrm{m}) \\
\min -\max \end{array}$} & \multirow[t]{2}{*}{$\mathrm{D}$} \\
\hline & MR & WS & & \\
\hline Amphicteis gunneri (Sars, 1835) & 83 & 208 & $5-7686^{a}$ & $\mathrm{CoD}$ \\
\hline Anobothrella antarctica (Monro, 1939) & 292 & 167 & $40-4099^{a}$ & $\mathrm{LaD}$ \\
\hline Sphaerodoropsis parva (Ehlers, 1913) & 167 & 42 & $128-3980^{\mathrm{b}}$ & $\mathrm{LaD}$ \\
\hline Harmothoe spinosa Kinberg, 1855 & 83 & 42 & $55-3400^{\mathrm{c}}$ & $\mathrm{CiP}$ \\
\hline Notoproctus oculatus antarcticus Arwidsson, 1811 & 296 & 208 & $218-3397^{d}$ & $\mathrm{CiP}$ \\
\hline Artacama proboscidea Malmgren, 1865 & 125 & 42 & $20-3380^{\mathrm{a}}$ & $\mathrm{BiD}$ \\
\hline Paramphinome australis Monro, 1930 & 702 & 333 & $128-3197^{e}$ & $\mathrm{LaD}$ \\
\hline Ampharete kergulensis MacIntosh, 1885 & 1617 & 83 & $64-2700^{\mathrm{f}}$ & $\mathrm{CiP}$ \\
\hline Augeneria tentaculata Monro, 1930 & 226 & 1583 & $80-2350^{9}$ & $\mathrm{CiP}$ \\
\hline Travisia kerguelensis MacIntosh, 1885 & 208 & 42 & $40-1784^{\mathrm{j}}$ & $\mathrm{LaD}$ \\
\hline Aricidea simplex (Day, 1963) & 83 & 83 & $35-1615^{\mathrm{h}}$ & $\mathrm{CoD}$ \\
\hline Aricidea strelzovi Hartmann-Schröder \& Rosenfeldt, 1990 & 6613 & 83 & $300-1600^{i}$ & $\mathrm{LaD}$ \\
\hline Maldane sarsi antarctica Arwidsson, 1811 & 184 & 333 & $75-1116^{j}$ & $\mathrm{CiP}$ \\
\hline Aricidea antarctica Hartmann-Schröder \& Rosenfeldt, 1988 & 42 & 125 & $20-1100^{\mathrm{k}}$ & $\mathrm{LaD}$ \\
\hline Amage sculpta Ehlers, 1908 & 42 & 42 & $244-1080^{b}$ & $\mathrm{LaD}$ \\
\hline Aphelochaeta cincinnata (Ehlers, 1908) & 570 & 458 & $61-1079^{a}$ & $\mathrm{LaD}$ \\
\hline Harmothoe magellanica MacIntosh, 1885 & 83 & 208 & $0-900^{1}$ & $\mathrm{CiP}$ \\
\hline Leodamas marginatus (Ehlers, 1897) & 167 & 958 & $20-640^{\mathrm{d}}$ & $\mathrm{LaD}$ \\
\hline Euphrosine antarctica Kudenov, 1993 & 101 & 500 & $60-494^{\mathrm{e}}$ & $\mathrm{LaD}$ \\
\hline Phyllochaetopterus monroi Hartman, 1967 & 42 & 125 & $270-485^{\circ}$ & $\mathrm{LaD}$ \\
\hline Nereis eugeniae Kinberg, 1866 & 167 & 125 & $40-455^{\mathrm{m}}$ & $\mathrm{LaD}$ \\
\hline Gyptis incompta Ehlers, 1897 & 202 & 500 & $300-445^{\mathrm{m}}$ & $?$ \\
\hline Axiothella antarctica Monro, 1930 & 119 & 42 & $207-344^{\mathrm{d}}$ & $\mathrm{CiP}$ \\
\hline Lysilla loveni macintoshi Gravier, 1907 & 42 & 42 & $25-335^{\mathrm{b}}$ & $\mathrm{CiP}$ \\
\hline Leitoscoloplos kerguelensis (MacIntosh, 1885) & 375 & 292 & $3-276^{j}$ & $\mathrm{LaD}$ \\
\hline Scalibregma inflatum Rathke, 1843 & 500 & 42 & $110-247^{\mathrm{d}}$ & $\mathrm{CoD}$ \\
\hline Autolytus charcoti Gravier, 1906 & 83 & 250 & $0-165^{\mathrm{b}}$ & $\mathrm{CiP}$ \\
\hline Typosyllis armillaris Müller, 1776 & 167 & 792 & $0-100^{\mathrm{n}}$ & $\mathrm{CoD}$ \\
\hline
\end{tabular}

Polynoidae only occurred in our samples in low species numbers and especially low individual numbers, possibly because the quantitative corers used in our study are known to more efficiently capture sessile organisms or those with low motility.

Significant differences between MR and WS polychaete assemblages also became evident by comparing the proportions of species representing different trophic guilds. The analysis of trophic guilds is an appropriate method for describing benthic communities, because they evidence the relationships of animals with their environment and/or interactions with other species (Muniz \& Pires 1999, Paiva 1993).

In our study, the trophic structures in the MR and WS assemblages were dominated by detritus feeders and predators, whereas a higher percentage of suspension feeders (which were of minor importance in both areas) in WS made up the main difference in such structures between the 2 regions. These results resemble data commonly reported for benthic communities in WS, where suspension feeders from different taxa dominate high Antarctic shelf communities. The hydrographic regime with strong currents provides sufficient food via vertical flux and advection, thus allowing the existence of dense populations of suspension feeders (Teixidó et al. 2002).

Most of the MR stations were located in fjords and channels, which typically form the MR and which are widely described in the literature (e.g. Syvitski et al. 1987). The prevailing environmental conditions with low water currents and exchange (Pinochet \& Salinas 1995), and frequently high sedimentation rates (Pickard \& Stantor 1980, Heiskanen \& Tallberg 1999) favour the existence of motile detritus feeders and predators, not only in case of polychaetes but also for other taxa, while suspension feeders are almost absent. This composition found in MR seems to be a typical feature for fjord and channel communities and is also reported for other regions worldwide (Rosenberg 2001). 
No significant differences became obvious in the evenness values between both areas. Due to relatively high species numbers and low numbers of specimens per species, evenness in both assemblages was high. In the polychaete-related literature, typically 1 or 2 species contribute considerably to the overall abundance with dominance values of $27 \%$ (Gambi et al. 1997) or even $36 \%$ (Gallardo et al. 1988). In contrast to our study, the maximum dominance values were lower and more species contributed to the $50 \%$ cumulative dominance value as compared to the literature data mentioned above. Hughes (1984) made similar observations in benthic invertebrate communities. Hughes' model, based on his observations, predicted a stable stage with a high dominance of a common species and few rare species, whereas high numbers of rare species with low abundance characterising early stages of colonization.

In the present study, the resulting pattern could also reflect disturbance in the 2 assemblags under study; the impact of ice scouring in WS and the impact of a permanent ice field with salinity gradients and high rates of sedimentation in $M R$, could maintain the assemblages in both areas in a stage of permanent early recolonisation (Gray 2001b, Gerdes et al. 2003). There clearly is some evidence to suggest a relationship between polychaete assemblage parameters and ice influence, but more quantitative documentation will be required to confirm this hypothesis.

In view of the common history of the Magellan region and the Antarctic, and considering the fact that they are neighbouring ecosystems, separated only by the Drake Passage and the Antarctic Convergence (which, however, acts like a filter for the dispersal of many aquatic organisms), the number of common species in both areas should be quite high. Surprisingly, we only found an $8 \%$ overlap of polychaete species and a $32 \%$ overlap at the genus level north and south of the Drake Passage. We have to keep in mind, however, that our 2974 polychaete specimens from 59 stations do not sufficiently represent the whole species inventories. Neither MR nor WS has been adequately sampled for this purpose, although our data set is the biggest considered so far. In a recent paper, Montiel (2005) reported a considerably higher overlap (>30\%) of polychaete species based, however, on quantitative and qualitative sampes as well as literature data. Our present results revealed further important insights into polychaete distribution patterns, but more comparable studies are urgently needed to answer the questions addressed with greater accuracy.

Acknowledgements. We are grateful to Dr. T. Brey for his help in the statistical analysis, to C. Ríos for his useful comments on the manuscript and to E. Mutschke and the Comité Oceanográfico Nacional (CONA) for providing the biological material from the CIMAR-Fiordo expedition. Support by DAAD grant no. A/00/10932 and DFG grant BR 1127 is gratefully acknowledged.

\section{LITERATURE CITED}

Arntz WE (1999) Magellan-Antarctic: ecosystems that drifted apart: summary review. In: Arntz WE, Ríos C (eds) Magellan-Antarctic: ecosystems that drifted apart. Sci Mar 63(Suppl 1):503-511

Arntz WE, Ríos C (1999) Magellan-Antarctic: ecosystems that drifted apart. Sci Mar 63(Suppl 1)

Barnes D, Brockington S (2003) Zoobenthic biodiversity, biomass and abundance at Adelaide Island, Antarctica. Mar Ecol Prog Ser 249:145-155

Brambati A, Fontolan G, Simeoni U (1991) Recent sediments and sedimentological processes in the Straits of Magellan. Boll Oceanol Teorica Applic 9:261-272

Bremec C, Elias R, Gambi M (2000) Comparison of the polychaete fauna composition from the Patagonian Shelf and Straits of Magellan: preliminary results from cruise Shinkai Maru IV, V, X and XI (1978-1979) and Second Italian Oceanographic Cruise (1991). Bull Mar Sci 67:189-198

Camus P (2001) Biogeografía marina de Chile continental. Rev Chil Hist Nat 74:587-617

Cañete J, Leighton G, Aguilera F (1999) Polychaeta from Aysén Fjord, Chile: distribution, abundance and biogeographical comparison with the shallow soft-bottom polychaete fauna from Antarctica and the Magellan Province. In: Arntz WE, Ríos C (eds) Magellan-Antarctic: ecosystems that drifted apart. Sci Mar 63(Suppl 1):243-252

Carmack E, Foster T (1975) Circulation and distribution of oceanographic properties near the Filchner Ice Shelf. Deep-Sea Res 22:77-90

Clark KR, Warwick RM (1994) Similarity-based testing for community pattern: the 2-way layout with no replication. Mar Biol 118(1):167-176

Clarke A, Johnston N (2003) Antarctic marine benthic diversity. Oceanogr Mar Biol Annu Rev 41:47-114

Cosson-Sarradin N, Sibuet M, Paterson G, Vangriesheim A (1998) Polychaete diversity at tropical Atlantic deep-sea sites: environmental effects. Mar Ecol Prog Ser 165: 173-185

Crame JA (1992) Trophic structure. In: Briggs E, Crowther P (eds) Paleobiology: a synthesis. Blackwell Science, Oxford, p 385-390

Dávila PM, Figueroa D, Müller E (2002) Freshwater input into the coastal ocean and its relation with the salinity distribution off austral Chile $\left(35-55^{\circ} \mathrm{S}\right)$. Cont Shelf Res 22:521-534

Draper N, Smith H (1981) Applied regression analysis, 2nd edn. Wiley Series in Probability and Mathematical Statistics. John Wiley \& Sons, New York

Eicken H (1992) The role of sea ice in structuring Antarctic ecosystems. Polar Biol 12:3-13

Ellingsen KE (2001) Biodiversity of a continental shelf softsediment macrobenthic community. Mar Ecol Prog Ser 218:1-15

Fauchald K, Jumars P (1979) The diet of worms: a study of polychaete feeding guilds. Oceanogr Mar Biol Annu Rev 17:193-284

Foggo A, Martin J, Matthew T, Frost R (2003) Estimating marine species richness: an evaluation of six extrapolative techniques. Mar Ecol Prog Ser 248:15-26 
Gallardo V (1984) Revisión actualizada a 1983 de la contaminación marina proveniente de fuentes terresteres en la región del Pacífico sudeste (Colombia, Chile, Ecuador, Panamá y Perú). Rev Comisión Permanente Pac Sur 14: 19-173

Gallardo V, Medrano S, Carrasco, F (1988) Taxonomic composition of the sublittoral soft-bottom Polychaeta of Chile Bay (Greenwich Island, South Shetland Islands, Antarctica). Ser Cient Inst Antartico Chileno 37:49-67

Gambi M, Mariani S (1999). Polychaetes of the soft bottoms of the Straits of Magellan collected during the Italian oceanographic cruise in February-March 1991. In: Arntz WE, Ríos C (eds) Magellan-Antarctic: ecosystems that drifted apart. Sci Mar 63(Suppl 1):233-242

Gambi M, Castelli A, Guizzardi M (1997) Polychaete populations of the shallow soft bottoms off Terra Nova Bay (Ross Sea, Antarctica): distribution, diversity and biomass. Polar Biol 17:199-210

Gaston G (1983) Benthic Polychaeta of the Middle Atlantic Bight: feeding and distribution. PhD thesis, Virginia Institute of Marine Science, Gloucester Point, VA

Gaston K (1996) Biodiversity: a biology of numbers and difference. Blackwell Science, Oxford, Berlin

Gerdes D (1990) Antarctic trials of the multi-box corer, a new device for benthos sampling. Polar Rec 26:35-38

Gerdes D, Montiel A (1999) Distribution patterns of macrozoobenthos: a comparison between the Magellan region and the Weddell Sea (Antarctica). In: Arntz WE, Ríos C (eds) Magellan-Antarctic: ecosystems that drifted apart. Sci Mar 63(Suppl 1):149-154

Gerdes D, Klages M, Arntz W, Herman R, Galéron J, Hain S (1992) Quantitative investigations on macrobenthos communities of the southeastern Weddell Sea shelf based on multibox corer samples. Polar Biol 12:291-301

Gerdes D, Hilbig B, Montiel A (2003) Impact of iceberg scouring on macrobenthic communities in the highAntarctic Weddell Sea. Polar Biol 26:295-301

Gray JS (1981) The ecology of marine sediments. Cambridge University Press, Cambridge

Gray JS (1994) Is deep-sea species diversity really so high? Species diversity of the Norwegian continental shelf. Mar Ecol Prog Ser 112:205-209

Gray JS (2000) The measurement of species diversity: an example from the continental shelf of Norway. J Exp Mar Biol Ecol 250:23-49

Gray JS (2001a) Antarctic marine benthic biodiversity in a world-wide latitudinal context. Polar Biol 24:633-641

Gray JS (2001b) Marine diversity: the paradigms in patterns of species richness examined. Sci Mar 65:41-56

Gray JS (2002) The species diversity of marine soft sediments. Mar Ecol Prog Ser 244:285-297

Gutt J, Helsen E, Arntz WE, Buschmann A (1999) Biodiversity and community structure of the mega-epibenthos in the Magellan region (South America). Sci Mar 63 (Suppl 1):155-170

Hartman O (1964) Polychaeta Errantia of Antarctica. Antarct Res Ser 3:1-131

Hartman O (1966) Polychaeta Myzostomidae and Sedentaria of Antarctica. Antarct Res Ser 7:1-158

Hartman O (1967) Polychaetous annelids collected by the USNS Eltanin and Staten Island cruises, chiefly from Antarctic seas. Allan Hancock Monogr Mar Biol $2: 1-328$

Hartman O (1978) Polychaeta from the Weddell Sea quadrant, Antarctica. Antarct Res Ser 26(4):125-223

Hartmann-Schröder O, Rosenfeldt P (1988) Die Polychaeten der 'Polarstern' - Reise ANT III/2 in die Antarktis 1984.
Teil 1. Euphrosinidae bis Chaetopteridae. Mitt Hambg Zool Mus Inst 85:25-72

Hartmann-Schröder O, Rosenfeldt P (1989) Die Polychaeten der 'Polarstern' - Reise ANT III/2 in die Antarktis 1984 Teil 2. Cirratulidae bis Serpulidae. Mitt Hambg Zool Mus Inst 86:65-106

Heiskanen A, Tallberg (1999) Sedimentation and particulate nutrient dynamics along a coastal gradient from a fjordlike bay to the open sea. Hydrobiologia 393(1-3):127-140

Hughes R (1984) A model of the structure and dynamics of benthic marine invertebrate communities. Mar Ecol Prog Ser 15:1-11

Knox G, Cameron D (1998) The marine fauna of the Ross Sea: Polychaeta. NIWA Biodivers Mem 108:1125

Knust R, Arntz WE, Boche M, Brey T and 5 others (2003) Iceberg scouring on the eastern Weddell Sea shelf (Antarctica): a benthic system shaped by physical disturbances? In: Huskes AL, Gieskes WW, Rozema J, Schorno RM, van der Vies SM, Wolff WJ (eds) Proc SCAR Biol Symp Amsterdam: Antarctic biology in a global context. Backhuys Publishers, Leiden, p 96-101

Kudenov J (1992) Amphinomidae and Euphrosinidae (Annelida: Polychaeta) principally from Antarctica, the Southern Ocean, and Subantarctic regions. Antarct Res Ser (58): 93-150

Lawrence G, Walter K (1979) Marine benthic diversity: a critique and alternative explanation. $\mathrm{J}$ Biogeogr 6: $115-126$

Licher F (2002) Revision der Gattung Typosyllis Langerhans, 1879 (Polychaeta: Syllidae): Morphologie, Taxonomie and Phylogenie. Abh Senckenb Natforsch Ges 551:1-336

Maurer D, Williams S (1988) Deep-sea polychaetous Annelida from Central America to the Antarctic Peninsula and Sandwich Islands. Int Rev Gesamten Hydrobiol 73(5): 659-701

Montiel A (2005) Biodiversity, zoogeography and ecology of polychaetes from the Magellan region and adjacent areas. Ber Polar-Meeresforsch 505:1-112

Montiel A, Gerdes D, Ríos C (2001) Distribución y abundancia del macrobentos en una microcuenca marina submareal del estrecho de Magallanes, Chile. An Inst Patagonia Ser Cienc Nat 29:117-133

Montiel A, Hilbig B, Rozbaczylo N (2002) New records to Chile of the family Paraonidae (Annelida: Polychaeta). Helgol Mar Res 56:134-139

Muniz P, Pires A (1999) Trophic structure of polychaetes in the Sao Sebastiao Channel (southeastern Brazil). Mar Biol 134(3):517-528

Naruse R, Aniya M (1992) Outline of glacier research project in Patagonia, 1990. Bull Glaciol Res 810:31-38

Orensanz J (1974) Anélidos poliquetos de la provincia biogeográfica magallánica. I. Catálogo de las especies citadas hasta 1974. Contrib Téc Lab Comunidades Bentónicas $1: 1-83$

Orensanz J (1990) The eunicemorph polychaete annelids from Antarctic and Subantarctic seas. Antarct Res Ser 52:1-183

Paiva PC (1993) Trophic structure of a shelf polychaete taxocoenosis in southern Brazil. Cah Biol Mar (35):39-55

Palma M, Quiroga E, Gallardo VA, Arntz A, Schneider W, Gerdes D, Hebbeln D (2005) Macrobenthic animal assemblages of the continental margin of Chile (23 to $\left.42^{\circ}\right)$. J Mar Biol Assoc UK 85:233-245

Parapar J, San Martin G (1997) 'Sedentary' polychaetes of the Livingston Island shelf (South Shetlands, Antarctica), with the description of a new species. Polar Biol 17 (6):502-514 
Petersen CG (1913) Valuation of the sea. 2. The animal communities of the sea bottom and their importance for marine zoogeography. Rep Dan Biol Ann Rev 16:229-311

Piccolo MC (1998) Oceanography of the western South Atlantic continental shelf from 33 to $5^{\circ} \mathrm{S}$ coastal segment $(5, W)$. Chapter 9. In: Robinson AR, Brink KH (eds) The sea. John Wiley \& Sons, New York, p 253-271

Pickard G, Stantor B (1980) Pacific fjords: a review of their water characteristis. In: Freeland H, Farme D, Levings (eds) Fjord Oceanography. Plenum Press, New York

Piepenburg D, Schmid M, Gerdes D (2002) The benthos off King George Island (South Shetland Islands, Antarctica): further evidence for a lack of a latitudinal biomass cline in the Southern Ocean. Polar Biol 25(2):146-158

Pinochet P, Salinas S (1995) Estructura térmica y salina de canales y fiordos adyacentes al los Campos de Hielo Sur. In: Comité Oceanográfico Nacional (ed) Informe de Crucero 1995. Litografía Carroza, Valparaíso, p 15-25

Reineck HE (1958) Kastengreifer und Lotröhre 'Schnepfe': Geräte zur Entnahme ungestörter, orientierter Meeresgrund-Proben. Senckenb Lethaea 39:42-48

Rex M, Stuart C, Hessler R, Allen J, Sanders H, Wilson D (1993) Global-scale latitudinal patterns of species diversity in the deep-sea benthos. Nature 365:636-637

Rosenberg R (2001) Marine benthic faunal successional stages and related sedimentary activity. Sci Mar 65 (Suppl 2):107-119

Rozbaczylo N (1985) Los anélidos poliquetos de Chile: índice sinonímico y distribución geográfica de especies. Monografía Biológica 3:1-284

Sanders H (1968) Marine benthic diversity: a comparative study. Am Nat 108:243-281

Editorial responsibility: Otto Kinne (Editor-in-Chief), Oldendorf/Luhe, Germany
San Martin G, Parapar J, Garcia F, Redondo M (2000) Quantitative analysis of soft bottoms infaunal macrobenthic polychaetes from South Shetland Islands (Antarctica). Bull Mar Sci 67:83-101

Snelgrove P (1998) The biodiversity of macrofaunal organisms in marine sediments. Biodivers Conserv 7:1123-1132

Stiller M (1996) Verbreitung und Lebensweise der Aphroditiden und Polynoiden (Polychaeta) im östlichen Weddellmeer un im Lazarevmeer (Antarktis). Ber Polar-Meeresforsch 185:1-200

Strelzov VE (1973) Polychaete worms of the family Paraonidae Cerruti, 1909 (Polychaeta, Sedentaria). Akad Nauk SSSR, Leningrad (English translation published in 1979 by Smithonian Institution, Washington, DC)

Strub PT, Mesias J, Montecino V, Rutllant J, Salinas S (1998) Coastal ocean circulation off western South America coastal segment. In: Robinson AR, Brink KH (eds) The sea, Vol 11. John Wiley \& Sons, New York, p 273-313

Syvitski JP, Burrell DC, Skei JM (1987) Fjords: processes and products. Springer-Verlag, New York, p 379

Teixidó N, Garrabou J, Arntz WE (2002) Spatial pattern quantification of Antarctic benthic communities using landscape indices. Mar Ecol Prog Ser 242:1-14

Thorson G (1957) Bottom communities (sublittoral or shallow shelf). Geol Soc Am Mem 67(1):461-534

Valdovinos C, Navarrete S, Marquet P (2003) Mollusk species diversity in the southeastern Pacific: Why are there more species towards the pole? Ecography 26:139-144

Wilson WH (1991) Competition and predation in marine softsediment communities. Annu Rev Ecol Syst 21:221-241

Zar JH (1999) Biostatistical analysis, 4th edn. Prentice-Hall, Upper Saddle River, NJ

Submitted: March 27, 2004; Accepted: June 11, 2004

Proofs received from author(s): July 5, 2005 